\title{
Phenolic compounds in native potato (Solanum tuberosum L.) cooking water, with potential antioxidant activity
}

\author{
Carmen Rosa ROJAS-PADILLA ${ }^{1 *}$ (D), Victor Javier VASQUEZ-VILLALOBOS ${ }^{1}$, Camilo Elber VITAL ${ }^{2}$, \\ Julio Cesar ROJAS ${ }^{1}$, Nelson Horacio RIOS ${ }^{3}$, Angel Pedro LUJAN ${ }^{3}$, Viviano Paulino NINAQUISPE ${ }^{1}$ (D), \\ Mario Sergio ESPINOZA ${ }^{4}$
}

\begin{abstract}
For over two decades, there has been an increasing interest in finding natural antioxidants, because they can protect the human body from free radicals and retard the progress of many chronic diseases. Phenolic compounds were identified and quantified in potato cooking water from freeze-dried slices with peel and from whole potato stored for 20 days. Extracts were obtained with an aqueous solution composed of $50 \%$ methanol and $0.5 \%$ acetic acid. Fifteen secondary metabolites were monitored using the Ultra Performance Liquid Chromatography system coupled to mass spectrometry (UPLC-MS / MS). A calibration curve (from $0.1 \mathrm{ng}$ to $100 \mu \mathrm{g}$ ) was generated and the data was analyzed using the software "MassHunter Workstation" VB 06.00, the results were expressed as $\mathrm{mg} / 100 \mathrm{~g}$ of sliced potato or raw potato. Principal Components Analysis (PCA) was performed using XLSTAT 2015 Software. The potato cooking water contains phytonutrients with potential antioxidant activity to prevent non-transmissible degenerative diseases. The metabolite content in the cooking water of the Huagalina native potato is directly related to the freshness of the product before cooking. Potato cooking water could be considered a neutraceutical food. However, further research is required to identify any other substances that can be harmful to health depending on the amount consumed.
\end{abstract}

Keywords: native potato; phytochemicals; boiled potato; chlorogenic acid; cancer.

Practical Application: Prevention of degenerative diseases for human population, consuming potato cooking water containing phytonutrients as it is not currently a habit to consume it.

\section{Introduction}

The history of potato (Solanum tuberosum L.) begins about 8000 years ago, on the northern part of Lake Titicaca, southern of Peru, which is 3800 meters above sea level in the Andes, South America, on the border of Bolivia and Peru (Spooner et al., 2005).

In that area, hunter-gatherer communities that had inhabited the southern part of the continent for at least 7000 years began to domesticate wild potato plants, growing in abundance around the lake, which they used as food and medicine. Potato is currently the fourth most important crop in the world for its high yield and nutritional value; it is an excellent source of carbohydrates, proteins, vitamins and minerals and is a rich source of antioxidants (Buono et al., 2009; Ezekiel et al., 2013). For two decades, there has been an increasing interest in finding natural antioxidants, because they can protect the human body from free radicals and slow down the progress of many chronic diseases (Kinsella et al., 1993). It has been demonstrated in vivo that the phenolic compounds of the potato are substances that have antioxidant, antiproliferative and anticancer properties (Han et al., 2007; Thompson et al., 2009) and the benefits for human health have also been tested in vitro (Madiwale et al., 2011; Ji et al., 2012), for their anti-inflammatory, analgesic, antimicrobial, neuroprotective, and cardioprotective action (Ong et al., 2013; André et al., 2014) and its antihyperglycemic effect (Singh \& Rajini, 2005). Chlorogenic acid was investigated for its protective effects on glutamate-induced neuronal cell death because the release of glutamate during brain ischemia triggers the death of neurons and prevents the increase of intracellular concentrations of $\mathrm{Ca}^{2+}$ caused by the addition of glutamate (Mikami \& Yamazawa, 2015). Studies have also shown that it is a phenolic compound that exerts anti-inflammatory and antioxidant activities; results suggest that chlorogenic acid protects against induced liver fibrosis, at least in part, through the suppression of oxidative stress in liver and hepatic stellate cells (Shi et al., 2016). On the other hand, caffeic acid has been studied in cervical cancer cell lines (HeLa cancer cells) and found to have significant antiproliferative effects on this type of cell (Markovic \& Tosovic, 2016; Ye et al., 2010). Another study shows that when caffeic acid was applied to hair cells at doses of 10 or $50 \mathrm{mg} / \mathrm{mL}$, they exhibited free radical scavenging 
and cisplatin-induced apoptosis activity (Choi et al., 2014). The effect of three phenolic acids (coumaric, ferulic and caffeic) on superoxide anion production, adhesion and migration of human lung cancer cell lines (A549) and colon adenocarcinoma (HT29-D4) has also been examined. The results demonstrated that these acids may act as active ingredients or agents against the cancers mentioned above during the adhesion and migration stages of tumor progression, which were the most common causes of cancer death in Europe with more than $50 \%$ of the total of cancer incidence and mortality (Znaor et al., 2013; Nasr Bouzaiene et al., 2015).

Despite growing interest, little is known about the use of these important phytochemicals, since almost $50 \%$ of phenolics are found in the peel and the adjacent tissues (Al-Weshahy \& Venket Rao, 2009; Albishi et al., 2013) which are precisely the parts that are not consumed by the population. According to Umadevi et al. (2013) raw, boiled, peeled or mashed potatoes have medicinal benefits and healing properties and even the water used to boil the potatoes can be used for medicinal purposes.

The aim of this research was to identify and quantify phenolic compounds found in potato cooking water in order to demonstrate scientifically that it contains bioactive antioxidant compounds with a potentially beneficial effect on human health.

\section{Materials and methods}

\subsection{Chemical materials}

HPLC grade standards were obtained from Sigma-Aldrich (USA): 3,5-dihydroxy benzoic acid, neochlorogenic acid, chlorogenic acid, 4-hydroxybenzoic acid, caffeic acid, syringic acid, vanillin, $p$-coumaric acid, ferulic acid, sinapic acid, 4-hydroxy-3-methoxy-cinnamaldehyde, coumarin, daidzein, genistein, 7-hydroxyflavone.

\subsection{Plant materials}

Fields trials were carried out in Santiago de Chuco - La Libertad at two experimental sites: El Zuro (EZ) and Huayatan Alto (HA).

- El Zuro (3 750 m.a.s.l.), sandy loam texture soil, with good drainage, moderate and deep slope, acid with a $\mathrm{pH}$ of 5.3 , electrical conductivity of $0.3 \mathrm{dS} / \mathrm{m}$ (no salt), organic matter: 6.4\% (very high), phosphorus $17 \mathrm{ppm}$ (high) and potassium $477 \mathrm{ppm}$ (very high), annual average temperature $9^{\circ} \mathrm{C}$ (dry cold climate) and organic manuring (Guano de Islas $2 \mathrm{MT} / \mathrm{ha}$ ) under drought conditions;

- Huayatan Alto (3 450 m.a.s.l), loamy soil with good drainage, with slightly pronounced and moderately deep slope, acid with a pH of 5.0, $1.5 \mathrm{dS} / \mathrm{m}$ (no salt) electrical conductivity, organic matter $5.2 \%$ (high), phosphorus $14 \mathrm{ppm}$ (average) and potassium $80 \mathrm{ppm}$ (low), with average annual temperature of $10{ }^{\circ} \mathrm{C}$ (temperate climate with presence of drizzle) and inorganic fertilization (180-200-160 kg of NPK /ha, under drought conditions.

Potatoes from EZ and HA were classified in two samples: a) Whole fresh potatoes were washed with tap water and the surface allowed to dry, manually cut into slices of $5 \mathrm{~mm}$ thickness, freeze-dried and packaged with liquid nitrogen in sealed jars. These samples will be called throughout the article as SP-EZ and SP-HA;

b) Whole potatoes were stored as raw material at $18.5-21.5^{\circ} \mathrm{C}$, $68-70 \%$ Relative Humidity for 20 days. These samples will be called throughout the articles as RP-EZ and RP- HA.

\subsection{Sample preparation}

The following treatments were used prior to extraction:

a) SP-EZ and SP-HA were unfreezed and then boiled in water $1 / 3 \mathrm{w} / \mathrm{w}$ (slices / water) for $20 \mathrm{~min}$ from boiling point. We analyzed phenolic compounds in SP water;

b) RP-EZ and RP-HA were boiled in water $1 / 3 \mathrm{w} / \mathrm{w}$ (potato/ water) for $20 \mathrm{~min}$ from start point. We analyzed phenolic compounds in RP water.

\subsection{Extraction}

Extraction solution (ES) used was an aqueous solution of $50 \%$ methanol (HPLC grade-Sigma Aldrich) and 0.5\% acetic acid (Fluka Analytical HPLC-grade), the same ES used by Narváez-Cuenca et al. (2012). An aliquot solution of boiling water of each two treatment (SP and RP) was placed with $500 \mu \mathrm{L}$ of the ES in vortex (VWR Analog Vortex Mixer, USA) 4 times for 10 seconds, sonicated (Branson Ultrasonic bath 3800 , USA) for $10 \mathrm{~min}$ at $4{ }^{\circ} \mathrm{C}$ and kept in ice (30 minutes). After centrifugation (Eppendorf 5424, Germany) at $15000 \mathrm{~g}$ for 10 minutes at $4{ }^{\circ} \mathrm{C}, 350 \mu \mathrm{L}$ of the supernatant was removed and put in a new tube. The process was repeated two more times with the resultant pellet, and the supernatants were pooled together. A final centrifugation (Eppendorf 5424, Germany) at $20000 \mathrm{~g}$ for $10 \mathrm{~min}$ at $4{ }^{\circ} \mathrm{C}$ was performed to remove any remaining tissue suspension, and stored at $-80^{\circ} \mathrm{C}$ until further analysis. Each treatment was repeated three times.

\subsection{UPLC - MS/MS analysis}

Extracts were automatically injected $(5 \mu \mathrm{L})$ in the system using UPLC (Agilent 1200 Infinity Series, USA) coupled to a Mass Spectrometry type triple Quadrupole (QqQ), (model 6430 Agilent Technologies, USA). Chromatographic separation was carried out on a column Zorbax Eclipe Plus $\mathrm{C} 18,1.8 \mu \mathrm{m}, 2.1 \times 50 \mathrm{~mm}$ (Agilent, USA) at $30^{\circ} \mathrm{C}$, in series with a guard column Zorbax SB-C18, $1.8 \mu$ m (Agilent, USA). The solvents used were: $(\mathrm{A})$ acetic acid $0.02 \%$ in water and (B) acetic acid $0.02 \%$ in acetonitrile (LC-MS grade, Fluka Analytical). The solvent flow rate was $0.3 \mathrm{~mL} / \mathrm{min}$. A linear gradient with the following proportions of solvent $\mathrm{B}$ was used: gradient from 0 to 11 minutes, 5 to $60 \% \mathrm{~B}$; from 11 to 13 minutes, 60 to $95 \% \mathrm{~B}$; from 13 to 17 minutes, $95 \% \mathrm{~B}$; from 17 to 19 minutes, 95 to $5 \% \mathrm{~B}$; from 19 to 20 minutes, $5 \% \mathrm{~B}$. The ionization method used in the mass spectrometry was an ESI (Electrospray Ionization) following these conditions: gas temperature of $300^{\circ} \mathrm{C}$, nitrogen flow rate of $10 \mathrm{~L} / \mathrm{min}$, nebulizer pressure of $35 \mathrm{psi}$ and capillary voltage 
of $4000 \mathrm{~V}$. The equipment was operated on mode MRM (Multiple Reaction Monitoring). The mass of the precursor ion/fragment $(\mathrm{m} / \mathrm{z})$ established was monitored by fragmentation tests of each molecule: 3,5 dihydroxybenzoic acid (155.02/137.01), chlorogenic acid (355.00/163.00), 4-hydroxybenzoic acid (139.12/121.00), 4- hydroxy-3-methoxy cinnamaldehyde (179.10/147.04), coumarin (147.06/91.00), daidzein (255.00/199.00), genistein (271.00/243.00), 7-hydroxyflavone (239.07/137.00), neoclorogenic acid (353.10/179.00), caffeic acid (179.00/135.00), syringic acid (197.00/121.200), vainillin (151.00/92.00), p-coumaric acid (163.04/119.00), ferulic acid (193.00/134.00), sinapic acid (223.00/164.10). The first eight were scanned in positive mode and the last in negative mode. A calibration curve $(0.1 \mathrm{ng}$ a $100 \mu \mathrm{g})$ using the respective standards of each metabolite was generated to determine the absolute quantification. The generated data were analyzed in the software "MassHunter Workstation" VB 06.00, which obtained the peak areas for each phenolic metabolite and the results were expressed in $\mathrm{mg} / 100 \mathrm{~g}$ of dry tissue.

\subsection{Statistical analysis}

Principal Components Analysis (PCA) was performed using Software XLSTAT 2015 (Digital license).

\section{Results and discussion}

In Figure 1, we report the phenolic compounds that have been identified and quantified in the cooking water of the Huagalina native potato. The main phenolic compounds (mg / $100 \mathrm{~g}$ of freeze dried sliced potato) are: Chlorogenic acid
(46.18), vanillin (16.03), p-coumaric acid (9.73), caffeic acid (9.41), 4-hydroxy -3-methoxy cinnamaldehyde (7.83), ferulic acid (5.97), neochlorogenic acid (2.07). In RP water, the main phenolic compound $\mathrm{mg} / 100 \mathrm{~g}$ of raw potato) is coumarin (9.31). The explanation for this higher concentration of metabolites in SP- potato cooking water could be: a) During boiling of potatoes in water, the contact surface between potatoes and water is higher, therefore is a great transfer of analytes to water increasing the concentration of phenolic compounds in water; b) The phenolic compounds are leached into the hot water and are often increased by the effect of the heat that extracts them and improves their bioavailability. They are highly reactive species that participate in the reactions that occur during the cooking process and are related to the cultivar: agro-technical processes, climatic conditions, maturity during the harvest, post-harvest manipulations (Stratil et al., 2006; Palermo et al., 2014).

It has been found in this research that the boiling water of potato contains phenolic compounds (phytonutrients) whose human health benefits have been demonstrated in several studies in vivo or in vitro: Chlorogenic acid (Cho et al., 2010; Sato et al., 2011; Shi et al., 2016), vanillin (Lirdprapamongkol et al., 2005) caffeic acid, coumarin and ferulic acid (Nasr Bouzaiene et al., 2015; Serafim et al., 2015) sinapic acid (Roy \& Prince, 2012).

According to the World Health Report (World Health Organization, 2002), insufficient consumption of fruit and vegetables reflects the economic, cultural and agricultural environment of the population and has become one of the 10 main risk factors attributed to mortality from non-communicable diseases. A low consumption of fruit and vegetables results in approximately

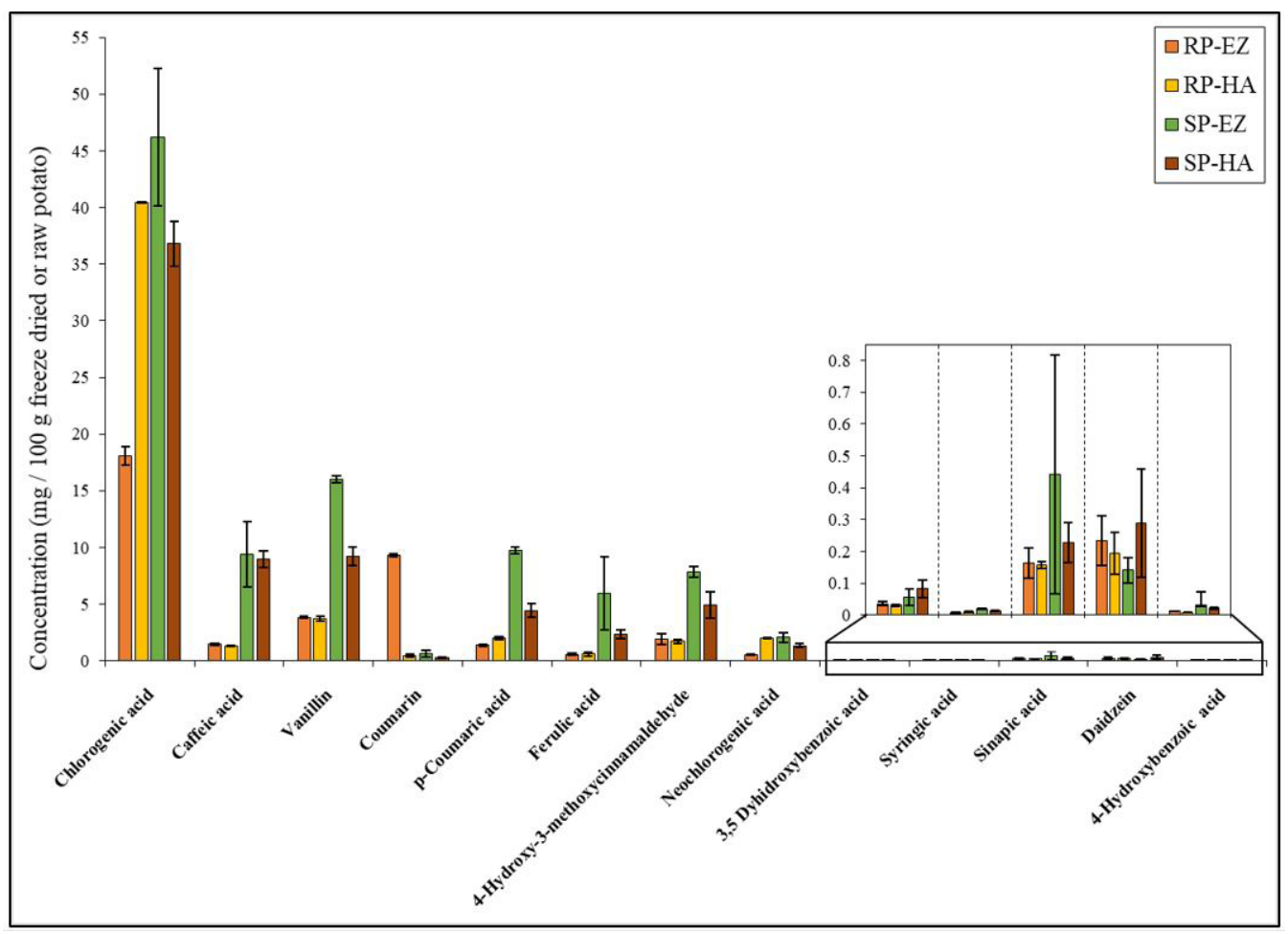

Figure 1. Phenolic compounds in potato cooking water. RP-EZ = Raw potatoes from El Zuro; RP-HA = Raw potatoes from Huayatan Alto; $\mathrm{SP}-\mathrm{EZ}=$ Slices potatoes from El Zuro; SP-HA = Slices potatoes from Huayatan Alto. 
$19 \%$ of gastrointestinal cancers, $31 \%$ of ischemic heart disease and $11 \%$ of cerebrovascular accidents. In total, 2.7 million deaths (4.9\%) and 26.7 million lost years of healthy life (1.8\%) were attributed to low consumption of fruit and vegetables.

Food and Agriculture Organization of the United Nations (2015) launched The Global Initiative on Food Loss and Waste Reduction that focuses on sustainable food production and diets, and sustainable consumption (for example, reducing food waste); in this sense, potato cooking water contains phytonutrients for disease prevention and as it is not currently a habit to consume it, if we encouraged its consumption instead of discarding it, it would help to complete the recommended intake of antioxidants that, according to World Health Organization (2004), should be five fruits and vegetables a day (aprox. $400 \mathrm{~g}$ ) for the diversity of antioxidants they provide.

The results shown in Figure 2, Principal component Analysis (PCA), indicate principal component F1 (72.01\%) values are in $\mathrm{X}$-axis and principal component $\mathrm{F} 2(16.20 \%)$ values are in $\mathrm{y}$-axis . Total variance account $88.22 \%$. F1 component shows that the metabolite content in the cooking water of the Huagalina potato is directly related to the freshness of the product (SP) before cooking, in accordance with what was mentioned by Carillo et al. (2012). Some studies report that cold storage $\left(<5^{\circ} \mathrm{C}\right)$ of potatoes either leads to an increase in the phenolic compounds or keeps it constant (Stushnoff et al., 2008; Lewis et al., 1999; Mqndy et al., 1966). In the cooking water of potatoes stored at $18.5-21.5^{\circ} \mathrm{C}$, 68-70\% Relative Humidity for 20 days (RP-EZ), only two phenolic compounds (daidzein and coumarin) were found with low correlation and significance $(p>0.05) . F 2$ component shows that there is a differentiation in the distribution of phenolic compounds due to climatic differences in crops (Reyes et al., 2004) and according to the type of conventional and organic fertilization (Hajslová et al., 2005). Eleven metabolites were distributed in SP cooking water but the highest correlation was found in SP-EZ, as can be seen on the Biplot, chlorogenic acid and its isomer neochlorogenic acid showed similar vector directions implying a high degree of relationship between them, the same as vanillin- siringic acid ; p-cumaric acid -siringic acid; ferulic acid-siringic acid ; sinapic acid-vanillin (Pearson correlation coefficient $>0.9724$ and $\mathrm{p}<0.05$ ).

In the organic cultivation carried out in EZ, whose source of nitrogen comes from Guano de Islas, chlorogenic acid (5-caffeoylquinic acid) and its isomer neochlorogenic acid (3-caffeoylquinic acid) have been identified giving a total of $48.25 \mathrm{mg} / 100 \mathrm{~g}$ of freeze-dried SP-EZ; this could be explained by the fact that in this type of crop, nitrogen is slowly taken up by the plant and reaches up to the last phase of tuber formation (Carillo et al., 2012); this allows the formation of glutamine and asparagine, which forms a complex with chlorogenic acid, according to what is reported by Adams (1994). With conventional cultivation (N-P-K) in SP- HA small quantities of phenolic compounds were found, with low correlation and significance $(\mathrm{p}>0.05)$.

For the results in this research, potato cooking water could be considered as a nutraceutical food. This potato water is a traditional medicine in the peruvian andes for illness and wellness

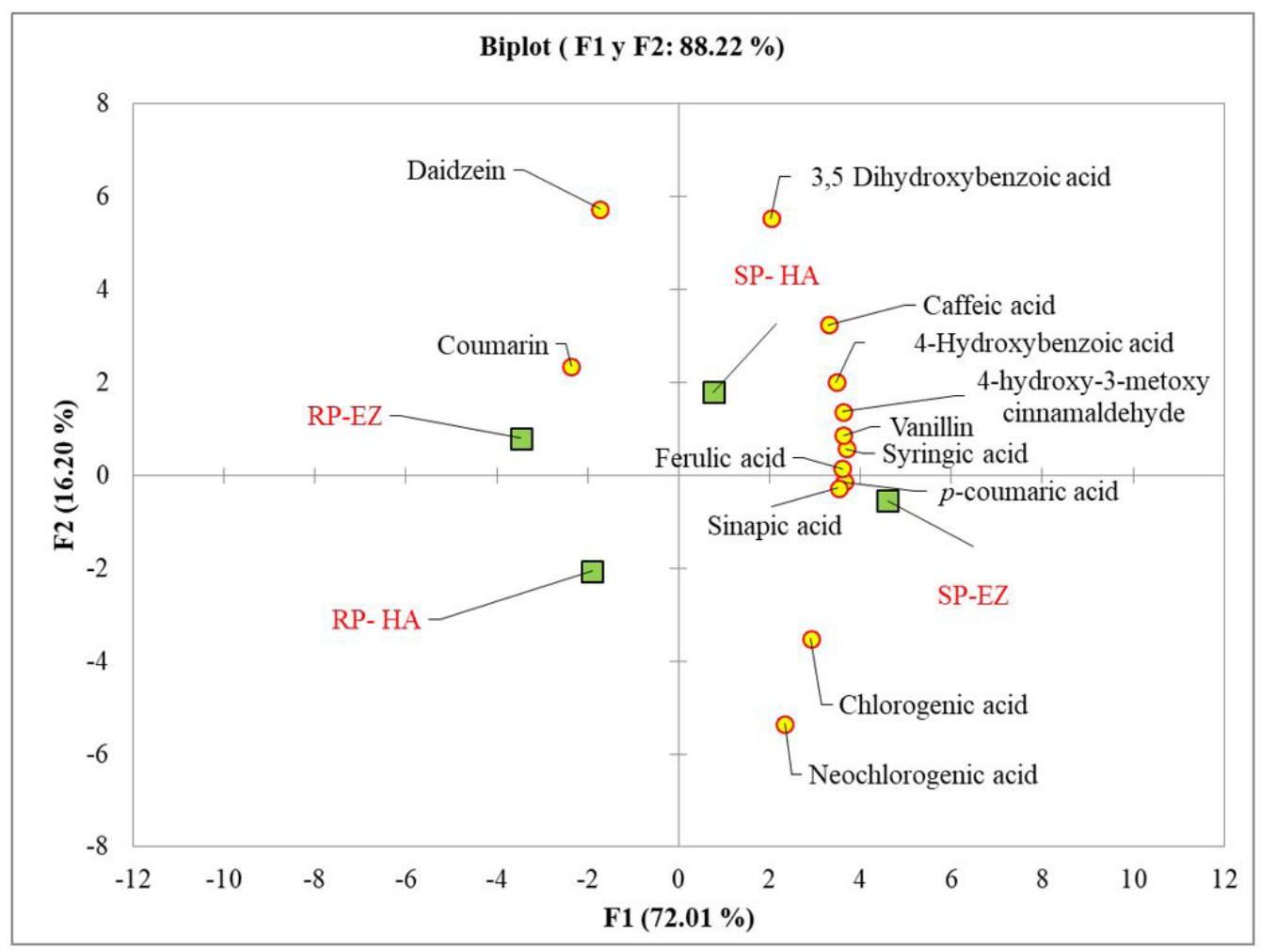

Figure 2. PCA of phenolic compounds in native potato (Solanum tuberosum L.) cooking water. RP-EZ = Raw potatoes from El Zuro; RP-HA = Raw potatoes from Huayatan Alto; SP-EZ = Slices potatoes from El Zuro; SP-HA = Slices potatoes from Huayatan Alto; F1 = Principal Component F1; F2 = Principal Component F2. 
purposes in humans. However, further research is required to identify any other substances that can be harmful to health depending on the amount consumed. The thirteen metabolites found in potato cooking water are the same as those found in raw potatoes of the same variety and origin (Rojas-Padilla \& Vasquez-Villalobos, 2016).

\section{Conclusions}

The cooking water of the Huagalina native potato SP-EZ and SP-HA contains phytonutrients with potential antioxidant activity to prevent non-transmissible degenerative diseases. The phenolic compounds with the higher concentrations were $(\mathrm{mg} / 100 \mathrm{~g}$ freeze dried SP): Chlorogenic acid (46.18), vanillin (16.03), $p$-coumaric acid (9.73), caffeic acid (9.41), coumarin (9.31), 4-hydroxy-3-methoxycinnamaldehyde (7.83), ferulic acid (5.97), neochlorogenic acid (2.07). According to, F1 (72.01\%), the metabolite content in the cooking water of the Huagalina potato is directly related to the freshness of the product before cooking. F2 (16.29\%) demonstrates that the highest correlations of phenolic compounds was found in SP-EZ ; chlorogenic acid - neochlorogenic acid, with high degree of relationship between them, the same as vanillin- siringic acid ; p-cumaric acid -siringic acid; ferulic acid-siringic acid; sinapic acid- vanillin (Pearson correlation coefficient $>0.9724$ and $p$ $<0.05$ ). These metabolites have been studied and the health benefits have been demonstrated in vivo or in vitro.

It is important to continue the study of the environmental conditions of potato cultivation, which are responsible for the different distribution of the phenolic compounds in both locations studied, highlighting the predominance of the genetics of the Huagalina variety in the profile of the phytonutrients found. Potato cooking water could be considered a nutraceutical food. However, further research is require to identify any other substances that can be harmful to health depending on the amount consumed.

\section{Acknowledgements}

Special thanks to Núcleo de Análise de Biomoléculas (NuBioMol) of UFV Viçosa (Brazil). We are also grateful to the Financing Agency for financial support with related equipment (FINEP, CNPq, FAPEMIG).

\section{References}

Adams, J. (1994). Green colour development in potato cooking water. Food Chemistry, 49(3), 295-298. http://dx.doi.org/10.1016/03088146(94)90174-0.

Albishi, T., John, J., Al-Khalifa, A., \& Shahidi, F. (2013). Phenolic content and antioxidant activities of selected potato. Journal of Functional Foods, 5(2), 590-600. http://dx.doi.org/10.1016/j.jff.2012.11.019.

Al-Weshahy, A., \& Venket Rao, A. (2009). Isolation and characterization samples of six potatoes varieties growing in Ontario. Food Research International, 42, 1062-1066. http://dx.doi.org/10.1016/j. foodres.2009.05.011.

André, C., Legay, S., Iammarino, C., Ziebel, J., Guignard, C., Larondelle, Y., Hausman, J.-F., Evers, D., \& Miranda, L. M. (2014). The potato in the human diet: a complex matrix with potential health benefits.
Potato Research, 57(3-4), 201-214. http://dx.doi.org/10.1007/ s11540-015-9287-3.

Buono, V., Paradiso, A., Serio, F., Gonnella, M., De Gara, L., \& Santamaria, P. (2009). Tuber quality and nutritional components of "early" potato subject to chemical haulm dessication. Journal of Food Composition and Analysis, 22(6), 556-562. http://dx.doi. org/10.1016/j.jfca.2009.01.001.

Carillo, P., Cacace, D., De Pascale, S., Rapacciuolo, M., \& Fuggi, A. (2012). Organic vs. traditional potato powder. Food Chemistry, 133(4), 1264-1273. http://dx.doi.org/10.1016/j.foodchem.2011.08.088.

Cho, A., Jeon, S., Kim, M., Yeo, J., Seo, K. Y., Choi, M. S., \& Lee, M. K. (2010). Chlorogenic acid exhibits anti-obesity property and improves lipid metabolism in high-fat diet-induced-obese mice. Food and Chemical Toxicology, 48(3), 937-943. http://dx.doi.org/10.1016/j. fct.2010.01.003. PMid:20064576.

Choi, J., Kim, S. H., Rah, Y. C., Chae, S. W., Lee, J. D., Md, B. D. L., \& Park, M. K. (2014). Effects of caffeic acid on cisplatin-induced hair cell damage in HEI-OCI auditory cells. International Journal of Pediatric Otorhinolaryngology, 78(12), 2198-2204. http://dx.doi. org/10.1016/j.ijporl.2014.10.013. PMid:25458160.

Ezekiel, R., Singh, N., Sharma, S., \& Kaur, A. (2013). Beneficial phytochemicals in potato: a review. Food Research International, 50(2), 487-496. http://dx.doi.org/10.1016/j.foodres.2011.04.025.

Food and Agriculture Organization of the United Nations - FAO. (2015). Global initiative on food loss and waste reduction. Rome: FAO. Retrieved from: http://www.fao.org/3/a-i4068e.pdf

Hajslová, J., Schulzová, V., Slanina, P., Janné, K., Hellenäs, K. E., \& Andersson, C. (2005). Quality of organically and conventionally grown potatoes: four-year study of micronutrients, metals, secondary metabolites, enzymic browning and organoleptic properties. Food Additives and Contaminants, 22(6), 514-534. http://dx.doi. org/10.1080/02652030500137827. PMid:16019825.

Han, K. H., Matsumoto, A., Shimada, K., Sekikawa, M., \& Fukushima, M. (2007). Effects of anthocyanin-rich purple potato flakes on antioxidant status in F344 rats fed a cholesterol-rich diet. British Journal of Nutrition, 98(5), 914-921. http://dx.doi.org/10.1017/ S0007114507761792. PMid:17559701.

Ji, X., Rivers, L., Zielinski, Z., Xu, M., MacDougall, E., Stephen, J., Zhang, S., Wang, Y., Chapman, R. G., Keddy, P., Robertson, G. S., Kirby, C. W., Embleton, J., Worrall, K., Murphy, A., De Koeyer, D., Tai, H., Yu, L., Charter, E., \& Zhang, J. (2012). Quantit.ative analysis of phenolic components and glycoalkaloids from 20 potato clones and in vitro evaluation of antioxidant, cholesterol uptake, and neuroprotective activities. Food Chemistry, 133(4), 1292-1298. http://dx.doi.org/10.1016/j.foodchem.2011.08.065.

Kinsella, J., Frankel, E., German, B., \& Kanner, J. (1993). Possible mechanisms for the protective role of antioxidants in wine and plant foods. Food Technology, 4, 85-89.

Lewis, C., Walker, J., \& Lancaster, J. (1999). Changes in anthocyanin, flavonoid and phenolic acid concentrations during development and storage of coloured potato (Solanum tuberosum L.) tubers. Journal of the Science of Food and Agriculture, 79(2), 311-316. http://dx.doi.org/10.1002/(SICI)1097-0010(199902)79:2<311::AIDJSFA199>3.0.CO;2-Q.

Lirdprapamongkol, K., Sakurai, H., Kawasaki, N., Choo, M.-K., Saitoh, Y., Aozuka, Y., Singhirunnusorn, P., Ruchirawat, S., Svasti, J., \& Saiki, I. (2005). Vanillin suppresses in vitro invasion and in vivo metastasis of mouse breast cancer cells. European Journal of Pharmaceutical Sciences, 25(1), 57-65. http://dx.doi.org/10.1016/j.ejps.2005.01.015. PMid:15854801. 
Madiwale, G., Reddivari, L., Holm, D., \& Vanamala, J. (2011). Storage elevates phenolic content and antioxidant activity but supresses antiproliferative and pro-apoptotic properties of colored- flesh potatoes against human colon cancer cell lines. Journal of Agricultural and Food Chemistry, 59(15), 8155-8166. http://dx.doi.org/10.1021/ jf201073g. PMid:21736387.

Markovic, S., \& Tosovic, J. (2016). Comparative study of the antioxidative activities of caffeoylquinic and caffeic acids. Food Chemistry, 210, 585-592. http://dx.doi.org/10.1016/j.foodchem.2016.05.019. PMid:27211685.

Mikami, Y., \& Yamazawa, T. (2015). Chlorogenic acid, a polyphenol in coffee, protects neurons against glutamate neurotoxicity. Life Sciences, 139, 69-74. http://dx.doi.org/10.1016/j.lfs.2015.08.005. PMid:26285175.

Mqndy, N., Geddedahl, S., \& Mobley, E. (1966). Effect of storage temperature on the cytochrome oxidase and polyphenol oxidase activities and phenolic content of potatoes. Journal of Food Science, 31(1), 32-37. http://dx.doi.org/10.1111/j.1365-2621.1966.tb15411.x.

Narváez-Cuenca, C.-E., Vincken, J.-P., \& Gruppen, H. (2012). Identification and quantification of (dihydro) hydroxycinnamic acids and their conjugates in potato by UHPLC-DAD-ESI-MS. Food Chemistry, 130(3), 730-738. http://dx.doi.org/10.1016/j.foodchem.2011.04.050.

Nasr Bouzaiene, N., Kilani Jaziri, S., Kovacic, H., Chekir-Ghedira, L., Ghedira, K., \& Luis, J. (2015). The effects of caffeic, coumaric and ferulic acids on proliferation, superoxide production, adhesion and migration of human tumor cells in vitro. European Journal of Pharmacology, 766, 99-105. http://dx.doi.org/10.1016/j. ejphar.2015.09.044. PMid:26432689.

Ong, K., Hsu, A., \& Tan, B. (2013). Anti-diabetic and anti-lipidemic effects of chlorogenic acid are mediated by AMPK activation. Biochemical Pharmacology, 85(9), 1341-1351. http://dx.doi.org/10.1016/j. bcp.2013.02.008. PMid:23416115.

Palermo, M., Pellegrini, N., \& Fogliano, V. (2014). The effect of cooking on the phytochemical content of vegetables. Journal of the Science of Food and Agriculture, 94(6), 1057-1070. http://dx.doi.org/10.1002/ jsfa.6478. PMid:24227349.

Reyes, L., Miller, J., \& Cisneros-Zevallos, L. (2004). Environmetal conditions influence the content and yield of anthocyanins and total phenolics in purple-and red flesh potatoes during tuber development. American Journal of Potato Research, 81(3), 187-193. http://dx.doi. org/10.1007/BF02871748.

Rojas-Padilla, C., \& Vasquez-Villalobos, V. (2016). Phenolic compounds with antioxidant capacity of the native Andean potato (Solanum tuberosum L.) Huagalina variety in La Libertad - Peru. Scientia Agropecuaria, 7(3), 333-340. http://dx.doi.org/10.17268/sci. agropecu.2016.03.22.

Roy, S. J., \& Prince, P. S. M. (2012). Protective effects of sinapic acid on Isosomal dysfunction in isoproterenol induced myocardial infarcted rats. Food and Chemical Toxicology, 50(11), 3984-3989. http://dx.doi. org/10.1016/j.fct.2012.08.017. PMid:22921837.

Sato, Y., Itagaki, S., Kurokawa, T., Ogura, J., Kobayashi, M., Hirano, T., Sugawara, M. Y., \& Iseki, K. (2011). In vitro and in vivo antioxidant properties of chlorogenic acid and caffeic acid. International Journal of Pharmaceutics, 403(1-2), 136-138. http://dx.doi.org/10.1016/j. ijpharm.2010.09.035. PMid:20933071.

Serafim, T., Milhazes, N., Borges, F., \& Oliveira, P. (2015). Caffeic and ferulic acid derivatives: use in breast cancer. In V. Preedy (Ed.),
Coffee in health and disease prevention. London: Academic Press. http://dx.doi.org/10.1016/B978-0-12-409517-5.00074-7.

Shi, H., Shi, A., Dong, L., Lu, X., Wang, Y., Zhao, J., Dai, F., \& Guo, X. (2016). Chlorogenic acid protects against liver fibrosis in vivo and in vitro through inhibition of oxidative stress. Clinical Nutrition, 35(6), 1366-1373. http://dx.doi.org/10.1016/j.clnu.2016.03.002. PMid:27017478.

Singh, N., \& Rajini, P. S. (2005). Free radical scavenging activity of an aqueous extracts of potato peel. Food Chemistry, 85(4), 611-616. http://dx.doi.org/10.1016/j.foodchem.2003.07.003.

Spooner, D., McLean, K., Ramsay, G., Waugh, R., \& Bryan, G. (2005). A single domestication for potato based on multilocus amplied fragment length polymorphism genotyping. Proceedings of the National Academy of Sciences of the United States of America, 102(41), 1469414699. http://dx.doi.org/10.1073/pnas.0507400102. PMid:16203994.

Stratil, P., Klejdus, B., \& Kubáñ, V. (2006). Determination of total content of phenolic compounds and their antioxidant activity in vegetables evaluation of spectrophotometric methods. Journal of Agricultural and Food Chemistry, 54(3), 607-616. http://dx.doi.org/10.1021/ jf052334j. PMid:16448157.

Stushnoff, C., Holm, D., Thompson, M., Jiang, W., Thompson, H., Joyce, N., \& Wilson, P. (2008). Antioxidant properties of cultivars and selections from the Colorado Potato Breeding Program. American Journal of Potato Research, 85(4), 267-276. http://dx.doi.org/10.1007/ s12230-008-9032-4.

Thompson, M., Thompson, H., McGinley, J., Neil, E., Rush, D., Holm, D., \& Stushnoff, C. (2009). Functional food characteristics of potato cultivars (Solanum tuberosum L.): phytochemical composition and inhibition of 1-methyl-1-nitrosourea induced breast cancer in rats. Journal of Food Composition and Analysis, 22(6), 571-576. http:// dx.doi.org/10.1016/j.jfca.2008.09.002.

Umadevi, M., Sampath, P., Bhowmik, D., \& Duraivel, S. (2013). Health benefits and cons of Solanum tuberosum. Journal of Medicinal Plant Studies, 1(1), 16-25.

World Health Organization - WHO. (2002). Reducing risks and promoting health life. Genebra: WHO. Retrieved from http://www. who.int/whr/2002/en/whr02_en.pdf?ua=1

World Health Organization - WHO. (2004). Global strategy on diet, physical activity and health. Genebra: WHO. Retrieved from http://www.who. int/dietphysicalactivity/strategy/eb11344/strategy_english_web.pdf

Ye, J. C., Hsiao, M. W., Hsieh, C. H., Wu, W. C., Hung, Y. C., \& Chang, W. C. (2010). Analysis of caffeic acid extraction from Ocimum gratissimum Linn. by high performance liquid chromatography and its effects on a cervical cancer cell line. Taiwanese Journal of Obstetrics \& Gynecology, 49(3), 266-271. http://dx.doi.org/10.1016/ S1028-4559(10)60059-9. PMid:21056309.

Znaor, A., Van den Hurk, C., Primic-Zakelj, M., Agius, D., Coza, D., Demetriou, A., Dimitrova, N., Eser, S., Karakilinc, H., Zivkovic, S., Bray, F., \& Coebergh, J. W. (2013). Cancer incidence and mortality patterns in South Eastern Europe in the last decade: gaps persist compared with the rest of Europe. European Journal of Cancer, 49(7), 1683-1691. http://dx.doi.org/10.1016/j.ejca.2012.11.030. PMid:23265703. 